\title{
A Arte Muralista: um breve tour
}

\section{Muralist Art: a brief tour}

\author{
Cristiane Rubbi \\ Mestre em História da Arte pela Universidade do Estado de Santa Catarina (UDESC) - cristiane.rubbi@gmail.com - \\ orcid.org/0000-0003-1623-5544 \\ Sandra Makowiecky \\ Doutora em Ciências Humanas pela Universidade Federal de Santa Catarina (UFSC). Professora da Universidade do \\ Estado de Santa Catarina (Udesc) - sandramakowiecky@gmail.com - orcid.org/0000-0002-9132-3643
}

\section{Resumo}

A arte mural apresenta, em sua concepção, uma pujante composição de liberdade artística, que foge da rigidez acadêmica, encontrando, assim, uma grande potencialidade expressiva. Amparado pelo crítico Mario Pedrosa (1981) e pela historiadora de arte Annateresa Fabris (1996), este trabalho consolida-se na tentativa de uma análise histórico-iconográfica que inicia nos primórdios da História da Arte e segue até a contemporaneidade, enveredando pelos conceitos de Foucault (2009). Com base em Panofsky (1989) e seus estudos iconológicos e iconográficos, olhamos para as obras de Hassis, Martinho de Haro, Portinari, Di Cavalcanti, Picasso, entre outros. Valendo-nos dos princípios corbusianos da arquitetura moderna, finalizamos este trabalho na seara das Políticas de Artes Públicas, com destaque à cidade de Florianópolis, no Estado de Santa Catarina.

Palavras-chave: Arte mural. Arte pública. Muralismo. Arquitetura moderna.

\begin{abstract}
The mural art presents in its conception a powerful composition of artistic freedom, that escapes of the academic rigidity, finding a great expressive potentiality. Held by the critic Mario Pedrosa (1981) and the art historian Annateresa Fabris (1996), this work is consolidated in the attempt of a historical-iconographic analysis that begins in the beginnings of the History of the Art until the contemporaneity, going by the concepts of Foucault (2009). Through Panofsky (1989) and his iconographic and iconographic studies we look at the works of Hassis, Martinho de Haro, Portinari, Di Cavalcanti, Picasso, among others. Drawing on the Corbusian principles of modern architecture, we finish this work in the field of Public Arts Policies, with emphasis on the city of Florianópolis, in the state of Santa Catarina.
\end{abstract}

Keywords: Mural art. Public art. Muralism. Modern architecture. 


\section{ARTE MURAL: CONCEITO E HISTÓRIA}

A arte da pintura em murais remonta aos primórdios da História da Arte, derivando das pinturas rupestres realizadas pelo homem pré-histórico, que as utilizavam como suporte para a produção de imagens, tanto no interior como no exterior das cavernas, pondera Souza (2012).

Inúmeros estudos foram realizados na tentativa de elucidar tantos questionamentos científicos, e algumas descobertas foram realizadas por pesquisadores das Universidades de Savóia e Aix-Marseille e do Centro Nacional de Pré-História da França, como, por exemplo, que os sofisticados elementos de animais representados nas paredes da Caverna Chauvet (Figura 1), localizada no sul da França, datam de 28.000 a 40.000 anos atrás, sendo os mais antigos registros de obras de arte rupestre encontrados no mundo pelo homem, de acordo com análises decorrentes da metodologia de radiocarbono da atualidade.

As mais antigas e famosas inscrições foram encontradas no território europeu: as da França, as Cavernas de Lascaux, de Nioux, de Chauvet e de Font-de-Gaume, e a da Espanha, a Caverna de Altamira. Na América Latina, também foram encontradas três cavernas significativas com arte rupestre em formato de murais, como, na Argentina, a Caverna de Las Manos e, no Brasil, as Cavernas de Pedra do Ingá (Paraíba) e Serra da Capivara (Piauí).

Figura 1 - Caverna de Chauvet, França.

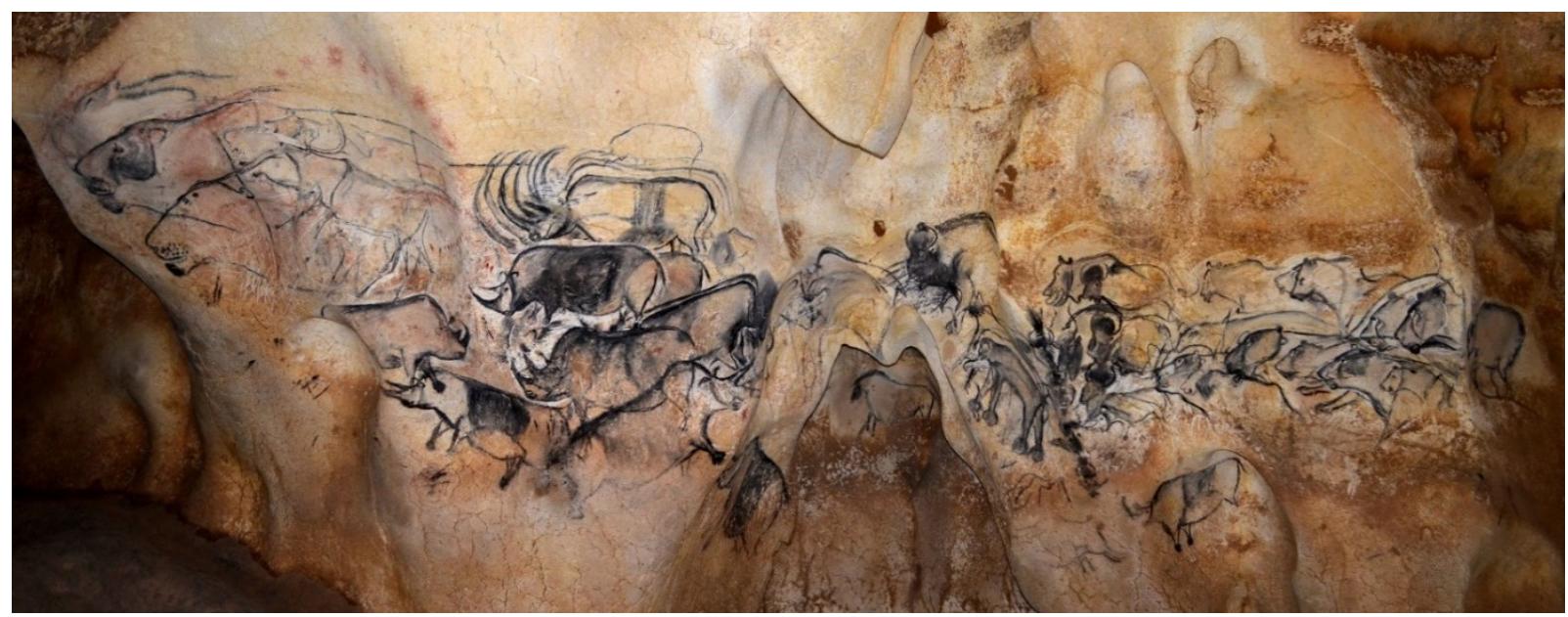

Fonte: Clottes ([20--?]).

Muralismo, ou simplesmente arte mural, também foi cultivado nas civilizações gregas e romanas, nas ruínas de Pompeia e Herculano, das quais restaram alguns poucos vestígios. 
Segundo Gomes (2018), há um consenso entre os pesquisadores contemporâneos, como Therese Burollet, Roger Benjamin e Pierre Vaisse, sobre a concepção geral que abarca as pinturas murais, cujas exigências convergem para que o tema da pintura se harmonize com o espaço, além de uma adequação visual ao contexto arquitetônico do entorno.

Além disso, Aracy Amaral (2003) acrescenta a importância da democratização social que a arte mural expõe a um contingente significativo de pessoas em contrapartida às pinturas em quadros, relegadas a paredes privadas ou a museus.

No século XIII, as obras de Giotto deram impressionante impulso à pintura muralista. Considerado o maior expoente da pintura renascentista, sua obra $O$ Encontro de São Joaquim $e$ Sant'Anna (Figura 2) expressa sua maturidade artística, integrando um conjunto de quarenta afrescos localizados na Cappella Degli Scrovegni, na cidade de Pádua, região de Vêneto, na Itália.

Figura 2 - O Encontro de São Joaquim e Sant'Anna ${ }^{1}$.

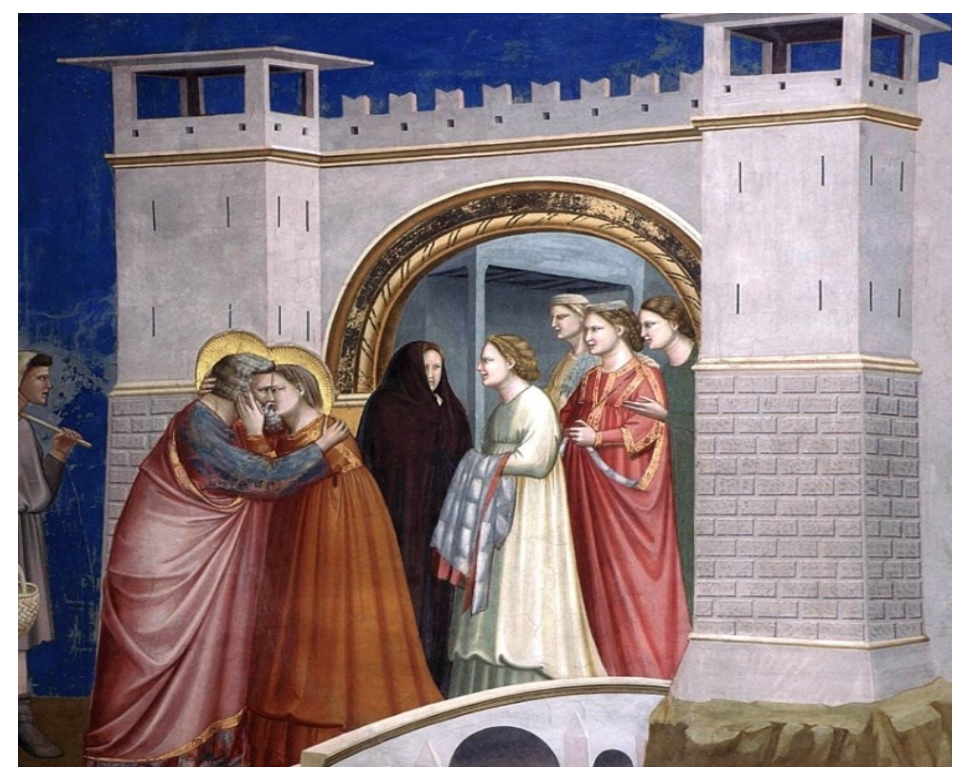

Fonte: Bondone (1304-06).

A partir do fim da Idade Média e início do Renascimento, surgiram grandes pintores dessa técnica, com obras-primas reconhecidas mundialmente na atualidade. Citamos duas do Renascimento: os afrescos de Michelangelo na Capela Sistina - O Juízo Final, e a Última Ceia, de Leonardo da Vinci.

${ }^{1}$ Tradução de: Incontro di Gioacchino e Anna alla Porta d'Oro. 
Partindo da definição do verbete contido no Dicionário Crítico da Pintura no Brasil (LEITE, 1988, p. 533), a palavra mural designa uma das grandes subdivisões da pintura em oposição à pintura de cavalete, adquirindo um caráter social, integralizando-se à superfície de uma parede, por meio de técnicas que vão, desde mosaicos, ao afresco, ao acrílico, etc.

De acordo com o historiador de arte Arthur Valle (2018), a técnica preferida utilizada na maioria das pinturas murais foi o marouflage, sendo este o processo de fixação de uma superfície flexível, como papel ou tela, sobre um suporte mais rígido, como muro ou madeira, fazendo uso de uma cola chamada maroufle, que, em francês, significa que endurece ao secar.

Brocos (1933) diferenciou a pintura mural da pintura de cavalete, frisando que a primeira primava pelo respeito à arquitetura local em fruição com a ambiência do entorno. Tal confluência fica perceptível inclusive na cromaticidade utilizada nessas pinturas, as quais almejam uma harmonização com a coloração do espaço arquitetônico envolvente, preservando a integridade da edificação. Em consonância, Price (1976) complementa que um acabamento fosco na superfície, a predominância de cores em tons pastéis esmaecidos e parcimônia no uso de efeitos de modelado e claro-escuro consistiam nas características formais desses trabalhos murais.

Tratado como muralismo pelos meios artísticos, nota-se que, no início do século $\mathrm{XX}$, essa técnica adquire maior visibilidade, em decorrência do movimento modernista, advindo de uma demanda crescente fomentada por instituições religiosas, pelo setor privado (famílias tradicionais de classe social elevada) e pelos poderes públicos, ideia ratificada também por Pedrosa (1981, $p$. 13), ao afirmar que a origem do muralismo moderno constitui-se

[...] de uma reação às limitações da pintura a óleo, que desde o movimento impressionista começou a ser ameaçada, de várias partes, por intenções monumentais contemporâneas, não fundadas numa nova arquitetura (mas em valores ou ideologia já cristalizada ou sem força inspiradora coletiva) e pela própria desagregação, diante de novas necessidades de expressão, da estética particular da pintura de cavalete (a regra das três unidades, etc.).

Atento as questões de seu tempo e em contínua articulação da arte com o momento social e político, o autor supracitado nos evidencia as inquietações do intelectual e do artista, contextualizando a pintura mural à dialética das relações histórico-sociais predominantes, almejando novas formas de ação para a transformação de seus meios, valendo-se da liberdade para 
saciar as novas demandas conectadas com uma linguagem mais adequada a arte social, voltada diretamente a coletividade, tornando a arte pública imbuída de um realismo poético.

\section{ARTE MURAL: BRASIL E ESTADO DE SANTA CATARINA}

No Brasil, diversos pintores modernos destacaram-se nesse gênero, como Portinari, Di Cavalcanti, Cícero Dias, Clóvis Graciano, Hassis, Martinho de Haro, Rodrigo de Haro, entre outros. O movimento modernista constituía uma busca simultânea pelo moderno e pelo nacional, contribuindo para a construção da identidade nacional, direcionando a arte, naquele período, para fins utilitários, em contraponto à ornamentação simplesmente.

De acordo com Annateresa Fabris (1996, p. 82),

[...] o movimento modernista ganha terreno nas instituições oficiais, desejosas de forjar a imagem de um país moderno. O ponto de encontro entre intelectuais/artistas e governo dá-se no âmbito da criação de uma unidade cultural, capaz de dar vida a uma ideia de nacionalidade que pusesse fim a dois males endêmicos: o divórcio da realidade nacional e a cópia de modelos estrangeiros.

Portanto, naquele momento constata-se uma reciprocidade entre os artistas modernistas e o governo propriamente dito, centrado na figura do ministro Gustavo Capanema (Ministério da Educação), em que os primeiros seriam os fins, operacionalizando artisticamente a construção da nacionalidade, e o segundo, os meios, com a abertura de espaços destinados a esses trabalhos, tornando-se o grande mecenas da produção cultural do período entre 1930 e 1945 . Imbricado a esse movimento, Foucault (2009), por meio de sua visão menos romantizada da arte, nos conduz por caminhos construídos por intencionalidades prévias presentes nas ordens discursivas, em detrimento da ingenuidade pretendida pela história tradicional, cujos objetos históricos seriam formações constituídas por descontinuidades e esquecimentos intencionais contidos em jogos de poder.

Ancoradas no movimento modernista da arte brasileira, que almejava a construção de uma identidade nacional, partimos na busca de subsídios facilitadores para a compreensão dos murais modernistas e suas características no Brasil.

Ferraz (1998, p. 17), na tentativa de consolidar tal pensamento, diz que:

a experiência muralística brasileira se encontra nesse período como uma extensão desse projeto de construção do moderno como cultura, como extensão dessa produção de cunho social, que sai do museu e vai para a rua. 
A expansão do campo pictórico filosófico/artístico na América Latina foi desencadeada, primeiramente, pelos artistas mexicanos, que focalizaram sua atenção para rumos sociopolíticos no período subsequente à Revolução Mexicana de 1910. Não limitado a somente seu território, o movimento muralista mexicano reverberou, significativamente, por toda a América Latina de forma dinâmica. Podemos dizer que, de certa maneira, tal movimento projetou o México à vanguarda da história das Artes Visuais, servindo de influência a outros segmentos de artistas mundiais.

Sucintamente, a arte mural tem uma vocação basilar socioeducativa adentrando a seara pedagógica, valendo-se, como forma de expressão, das querelas existenciais contidas no campo antropológico, econômico, geopolítico e cultural, corroborando, a seu modo, na construção de um novo pensamento crítico no modo de ver a arte, retirando-lhe a aura mítica circunscrita a uma restrita classe social mais abastada.

A abordagem sociológica da História da Arte, adotada por Annateresa Fabris (1990), corrobora esse pensamento crítico, inclusive ao afirmar que a influência do movimento muralista nas obras do pintor brasileiro Cândido Portinari, faz-se como uma legítima demonstração da preocupação social na arte brasileira, não enveredando ipsis litteris $^{2}$ pelos caminhos traçados, prioritariamente e fortemente, pelo movimento muralista mexicano na seara política pósrevolução.

Tanto para Pedrosa (1981) quanto para Fabris (1990), seria mais assertivo afirmar que Portinari e os muralistas mexicanos influenciaram-se pelas mesmas matrizes. Deste modo, provêm as semelhanças à renascença italiana e à escola de Paris.

Ao pesquisar o tema da arte muralista, não há como não percorrer o caminho das pinturas murais de Pompeia até os afrescos das igrejas medievais ou, por assim dizermos, período decorativo renascentista, no qual a arte mural estabelece um sistema relacional de comunicação que suscita outros diversos questionamentos relativos ao espaço, às formas, às expressões sempre voltadas à monumentalidade ${ }^{3}$.

Esses murais seriam potencialidades evocativas do ideário de uma proposta de reforma urbana, quiçá fundamentadas na ideologia do espaço da cidade compreendido como lugar gerador

\footnotetext{
${ }^{2}$ Tradução: pelas mesmas letras, textualmente, literalmente. https://www.dicionariodelatim.com.br/ipsis-litteris/.

${ }^{3}$ Monumentalidade: palavra que provém do latim moneo, monere, cuja definição seria instruir e fazer recordar por meio da arte.
} 
de transformação? Talvez se contrapunham ou integravam-se aos monumentos históricos existentes. A arte muralista brasileira originária no período modernista, com ideias fomentadoras do identitário nacional, vinculava uma visão do coletivo histórico do país, como também evidenciava as querelas sociais.

Cândido Portinari foi um grande expoente do muralismo nacional que, com grande destreza, fez uso do muralismo para demonstrar sua concepção pessoal de mundo, defendendo a ideia de que não existe obra neutra, de certa maneira dialogando com Foucault, ao defender a existência da não homogeneidade discursiva pretendida pela história tradicional, sofrendo intervenções intencionais em suas construções discursivas.

Segundo o pintor (PORTINARI, 1947), a arte era portadora de uma ação intrínseca de consciência crítica dialética, sendo a pintura mural a mais adequada para a arte social (seu mote principal), porque o muro geralmente pertence à coletividade e, ao mesmo tempo, conta uma história, interessando a um maior número de pessoas 4 .

Figura 3 - Painéis Guerra e Paz.
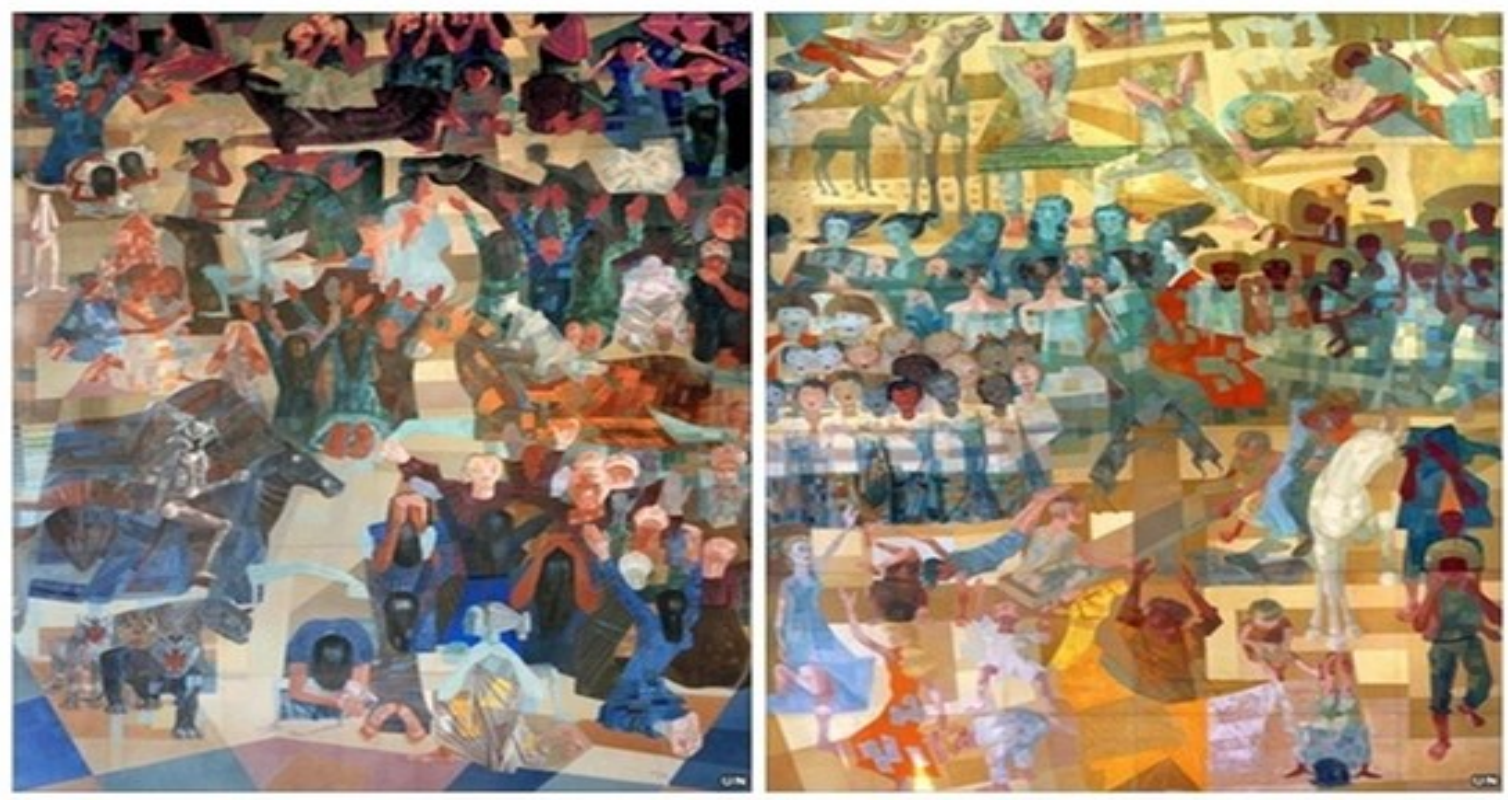

Fonte: Portinari (1952-56).

Os painéis Guerra e Paz, de Portinari (Figura 3), considerados pelo próprio artista como sua obra mais relevante, podem ser analisados como obra-síntese de toda sua vida por apreender seu

\footnotetext{
${ }^{4}$ Ideário discursivo realizado em uma palestra em Buenos Aires, Argentina, no dia 26 de julho de 1947.
} 
forte comprometimento com o ser humano, de acordo com seu filho, João Cândido Portinari (2010). Obra composta por 28 painéis ao todo, pintados durante nove meses, depois de quatro anos de estudos, com a elaboração de 180 esboços e duas maquetes. Cada mural mede 14 metros de altura e aproximadamente 11 metros de largura, constituídos de placas de madeira compensada naval com dois metros de altura por cinco metros de largura cada uma, pesando 75 quilos cada placa. A área total pintada perfaz $280 \mathrm{~m}^{2}$, comparativamente maior do que a obra o Juízo Final, de Michelangelo, localizada na Capela Sistina $\left(167 \mathrm{~m}^{2}\right)$.

Impressionado por Pablo Picasso no contato que teve em Nova York no ano de 1939, cujo impacto foi sentido ao deslumbrar a obra Guernica, de 1937 (Figura 4), esta o influenciou significativamente na construção dos arcabouços para os painéis Guerra e Paz (Figura 3), encomendados pelo governo brasileiro para comporem o acervo da nova sede da ONU, em Nova York, como forma de doação nacional. Ressaltamos que suas principais influências artísticas vieram:

a) da Renascença italiana: Giotto, Piero Della Francesca, Fra Angélico;

b) da Escola de Paris: Matisse, Modigliani e Picasso.

Notório afirmarmos que Portinari atingiu seu ápice na carreira artística com os murais, sendo reconhecido mundialmente como um dos maiores expoentes da pintura social brasileira no século $X X$, inclusive sendo idolatrado pelos modernistas brasileiros pela impecável plasticidade de suas obras e harmonização com a arquitetura (WILHELM, 2006).

A universalidade da arte mural fica evidenciada na análise da produção artística de alguns pintores que, por meio do silêncio das pinceladas, esbravejam em brados fortes as querelas da existencialidade humana, demonstrando a insignificância do espaço físico geográfico perante a grandeza do ideário muralista, que exalta toda sua potencialidade como função social em obras, como observamos nos painéis Guerra e Paz, de Portinari (Brasil/SP), a Guernica, de Picasso (França) e O Contestado - Terra Contestada, de Hassis (Brasil/SC).

O movimento muralista pode ser apreendido como uma necessidade humana de expressividade da vida por imagens, provinda desde as cavernas com sua arte mural rupestre repleta por desenhos de animais, transitando intensamente pela Renascença de cunho ardente da religiosidade humana e adentrando a contemporaneidade com forte mote social, seja pela exaltação do nacionalismo vindo do período modernista (Di Cavalcanti, Clóvis Graciano e Martinho de Haro), como no formato de denúncia filosófica/social (Portinari, Picasso, Hassis), potência esta 
que se utiliza de um sistema relacional artístico ilimitado, enaltecendo a arte como a forma de "expressão do indizível, que exprime o inexprimível e traduz o intraduzível", segundo as palavras do mestre Leonardo da Vinci (LEONARDO DA VINCI, 2016, p. 8).

Por intermédio do método de análise iconográfica e interpretação iconológica de Panofsky (1989), esmiuçaremos os painéis de reconhecidos muralistas nacionais e internacionais, anteriormente referenciados neste trabalho.

Como leitores ocidentais, da arte mural do painel Guerra e Paz, de Portinari (Figura 3), iniciaremos nossa descrição da esquerda para a direita, portanto, pelo painel Guerra. Portinari faz menção às duas grandes guerras mundiais nessa obra. Com uma estrutura verticalizada, o painel apresenta o predomínio da cor azul, sugerindo melancolia, e por ser simbologicamente uma cor fria, talvez o sofrimento do povo assolado pela guerra. Todavia, esse painel não é representado com armas, soldados e combates, mas generosamente com clamores, por meio de pessoas prostradas de joelhos com os braços erguidos ou encurvados com as mãos espalmadas, ou, ainda, em prantos com as mãos no rosto. Cadáveres adultos são velados e mulheres têm nos braços crianças mortas, imagem que nos remete facilmente à Pietá, de Michelangelo, pondera Mariani (2013).

Notabilizamos que, na dor, pintada por Portinari, ninguém está sozinho, as pessoas estão em grupos. O lamento que se ergue está representado por uma humanidade que chora coletivamente, que se solidariza (MARIANI, 2013). No canto inferior direito, perfilam-se os cavaleiros do Apocalipse como representantes do mal, acima das feras (hienas), que simbolizam os governantes que detêm esse poder nas mãos, movidos pela ganância, que matam por meio da espada, da fome. O painel faz-nos refletir sobre uma dicotomia expressa em pinceladas. Se a guerra representa a ausência de Deus, Portinari a define por meio de uma presença misteriosa, levando nosso olhar ao céu mediante o clamor das vítimas, no lamento por sua ausência, evidenciando de certa maneira, sua existência. Vale lembrar que o pintor assumidamente declarava-se ateu ou agnóstico.

Nos dois painéis, torna-se perceptível a predominância de cores consideradas opostas, em que na Guerra o azul evidencia-se com toda sua frieza, enquanto na Paz o amarelo sobressai-se intensamente com todo seu calor. 
No painel $P a z$, observamos a celebração da vida com o predomínio de cores luminosas. Até mesmo os poucos tons azuis presentes são entrecortados pelos tons quentes de amarelo e vermelho, dissociando a melancolia remetida pela cor fria, em minoria. Também de estrutura vertical, esse painel remete-nos à alegria presente na esperança do homem do interior, na vida simples, no trabalho, nas cenas de colheita, na festa, nos brinquedos. Com facilidade, torna-se perceptível a compreensão do fascínio do pintor pela infância, representada pela memória do adulto, pela inocência, pela esperança de um mundo novo e melhor. Coro de mulheres felizes, crianças a brincar por toda parte - são nessas cenas harmoniosas que a obra Paz consagra-se. Ainda, festa na fazenda ou tarde de domingo na praça, pondera Mariani (2013). Expressamente, não podemos mencionar que Deus encontra-se ali representado, porém sua presença misteriosa fica implícita na narrativa da vida que impulsiona a humanidade a mover-se ao trabalho com alegria, agradecimento ou, ainda, por meio do canto, da brincadeira de criança. Podemos interpretar que a $P a z$ responde ao clamor que provém da Guerra, sendo a vida movida por mãos celestiais que habitam entre nós (MARIANI, 2013). Nessa obra, a arte mural apresenta robusto cunho social.

Perceptível a influência de Picasso nos trabalhos de Portinari, porém não podemos afirmar que pertença à escola picassiana, devido a ter adquirido uma personalidade artística própria. Ambos nutriam, em comum, a preocupação em pensar a sociedade que os rodeavam, produzindo dessa forma, um relevante retrato de seu tempo.

A obra Guernica, de Picasso (Figura 4), é descrita neste trabalho em decorrência de seu forte sentimento impactante deixado em Portinari, ao entrar em contato com a obra exposta no Museu de Arte Moderna de Nova York (MOMA), em 1939.

A origem da obra Guernica deve-se a uma encomenda do governo republicano de Madri, por um afresco destinado ao pavilhão espanhol na Exposição Universal de Paris, na França, ocorrida no período de 25 de maio a 25 de novembro de 1937. Repleta de dramaticidade e tom trágico, essa obra tornar-se-ia ícone do cubismo, como manifesto antibélico da História da Arte do século XX, segundo Rossetto e Mori (2016). 
Figura 4-Guernica.

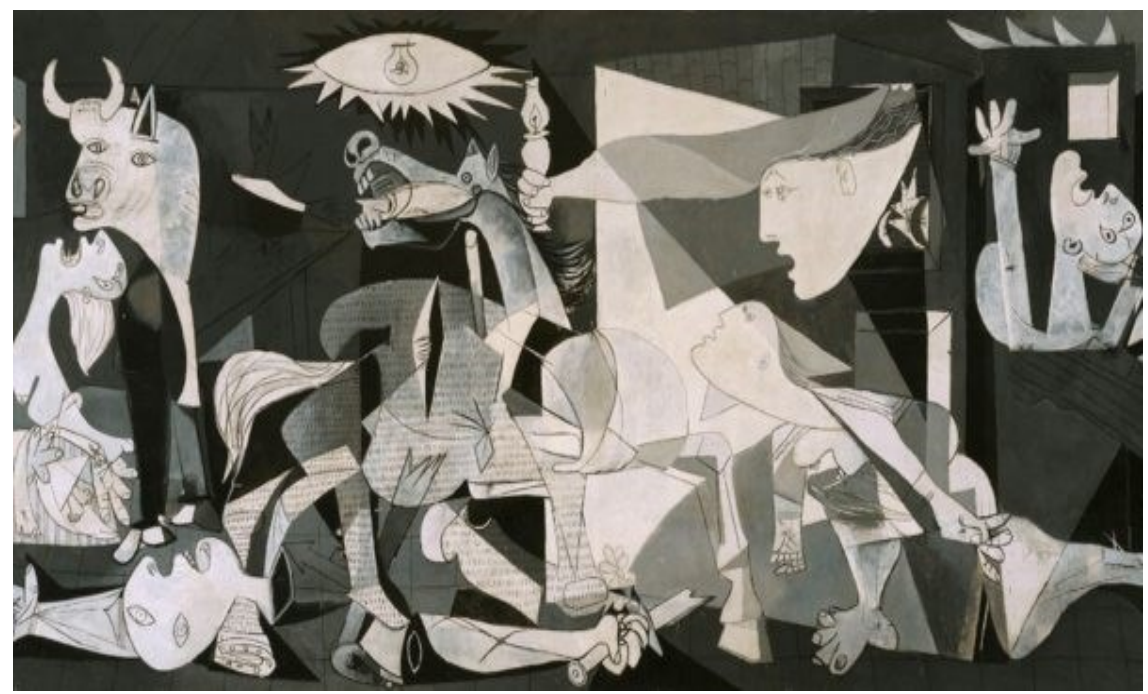

Fonte: Picasso (1937).

Guernica, obra impactante tanto pelo tamanho $(3,49 \mathrm{~m} \times 7,77 \mathrm{~m})$ como pela expressividade e legado mundial, demorou aproximadamente trinta dias para sua execução. Picasso, em 1937, deposita em pinceladas toda sua consternação, seu horror e indignação pela guerra, utilizando-se de um fato marcante da história como tema de sua obra, que foi o bombardeio da cidade basca pelos nazistas durante a Guerra Civil Espanhola.

Observando a obra, deparamo-nos com figuras geometricamente decompostas, no estilo cubista, que expressam dor, aflição e real sofrimento humano, retratado em forma de pedaços de nossa realidade, sobre uma composição triangular. Amparada pelas cores em tons cinza e pelo branco e preto, a temática atinge um elevado grau de desespero e medo, remetendo-nos com facilidade à morte, ao desumano, à guerra e à destruição. Dotado de fortes aspectos simbólicos, encontrados na figura do touro, da flor e da mão que segura uma lamparina (na parte superior, no centro), enveredamos pelo ideário da luta, da violência, mas que concomitantemente nos conduz a um sentimento de esperança e recomeço. Ao deslocar seu olhar para o canto superior direito da obra, a figura de um homem com os braços estendidos e as mãos espalmadas em súplica faz-nos rememorar similaridades encontradas na obra de Goya de 1808 sobre os fuzilamentos, intitulada Três de maio de 1808 em Madri, considerada como uma das imagens mais memoráveis da desumanidade do homem para com ele mesmo ou em Portinari, na série Retirantes (na obra 
Enterro na Rede, 1944), com o retrato de denúncia social da situação do trabalhador brasileiro, e os painéis Guerra e Paz, neste trabalho anteriormente referenciados.

Simbologicamente, o touro (bravura e virilidade) e o cavalo (guia da alma para o mundo dos mortos), elementos populares na cultura espanhola, estão na obra Guernica, expressando a tentativa de destruição dos ideais defendidos pelos cidadãos espanhóis durante a ação do bombardeio e os elementos que parecem conter escritos no seu interior, por folhas de jornal, estão retratando o meio pelo qual Picasso obteve a informação do ataque ocorrido em Guernica, os jornais. Quanto à figura emblemática do touro, especificamente, as interpretações podem ser múltiplas, desde a simples afirmação do fascínio de Picasso pelo touro (sendo encontrado inclusive em várias de suas obras), representando a resistência do povo espanhol, como também expressando a figura do próprio General Franco e o poder fascista, com sua brutalidade e força. Entre o touro e o cavalo, percebemos a presença de um pássaro branco, simbolizando a paz violada na Espanha, talvez ratificando o porquê de estar entre o touro (poder fascista do General Franco) e o cavalo (resistência do povo, elevação das almas ao céu), figura esta que se encontra transpassada por uma lança mortal e que expressa em sua face um grito de dor.

Talvez os edifícios em chamas surgissem não apenas da destruição de Guernica, mas também da destruição geral causada durante a Guerra Civil, enquanto a mulher que arrasta uma de suas pernas, encontrada na parte inferior direita da obra, referencie-se a todas as pessoas que tentaram escapar do bombardeio. Entretanto, na parte superior e central da obra, observamos uma figura em formato de olho, sugerindo o olho de Deus, que tudo vê. Se nos detivermos na parte inferior da obra, veremos um elemento mutilado, sugerindo a imagem de um guerreiro abatido em guerra, porém carrega em uma de suas mãos a espada quebrada, símbolo de resistência e próximo da figura de uma flor, na esperança da reversão dessa posição, conduzindo-nos ao pensamento de que, enquanto houver resistência, haverá esperança. Incontestável sua função social e similaridade com Portinari em Guerra e Paz.

A pedido do pintor, Guernica ficou na França até que a Espanha, em 1981, com a morte do ditador Francisco Franco (mandante do bombardeio à cidade basca de Guernica em 26 de abril de 1937), tivesse restaurado sua democracia no país.

Retornando à ambiência brasileira, além do significativo trabalho de Portinari, faz-se jus ressaltar a arte mural catarinense, que muito contribuiu ao movimento muralista que aflorava pelo 
país no período modernista, sendo representada por artistas de grande expressão regional, como Hiedy de Assis Corrêa (Hassis) e Martinho de Haro.

Muralista de grande reconhecimento estadual, Martinho de Haro, de cuja arte mural apropria-se com destreza, possui uma obra que simboliza toda a pujança da indústria catarinense, refletindo muito a sua visão dicotômica entre o progresso industrial crescente que verticaliza a cidade e a pacata Florianópolis com sua natureza exuberante e tranquilidade cotidiana (que muito aprecia pessoalmente). A obra é composta por mosaicos no saguão aberto do antigo Palácio da Indústria do Estado (Figura 5), sede da FIESC entre 1963 e 1983 e que hoje abriga a Fundação de Amparo à Tecnologia e ao Meio Ambiente (FATMA). O prédio é situado na Rua Felipe Schmidt, $\mathrm{n}$. 485, região central da cidade de Florianópolis. Em decorrência de sua relevância artístico/histórica, foi declarado patrimônio cultural de Santa Catarina, pela Lei $n^{\circ}$ 14.128, de 05 de outubro de 2007 (FLORIANÓPOLIS, 2007).

Figura 5 - Sem Título. Mural em pastilhas, localizado na Rua Felipe Schmidt, n. 485, Florianópolis 5 .

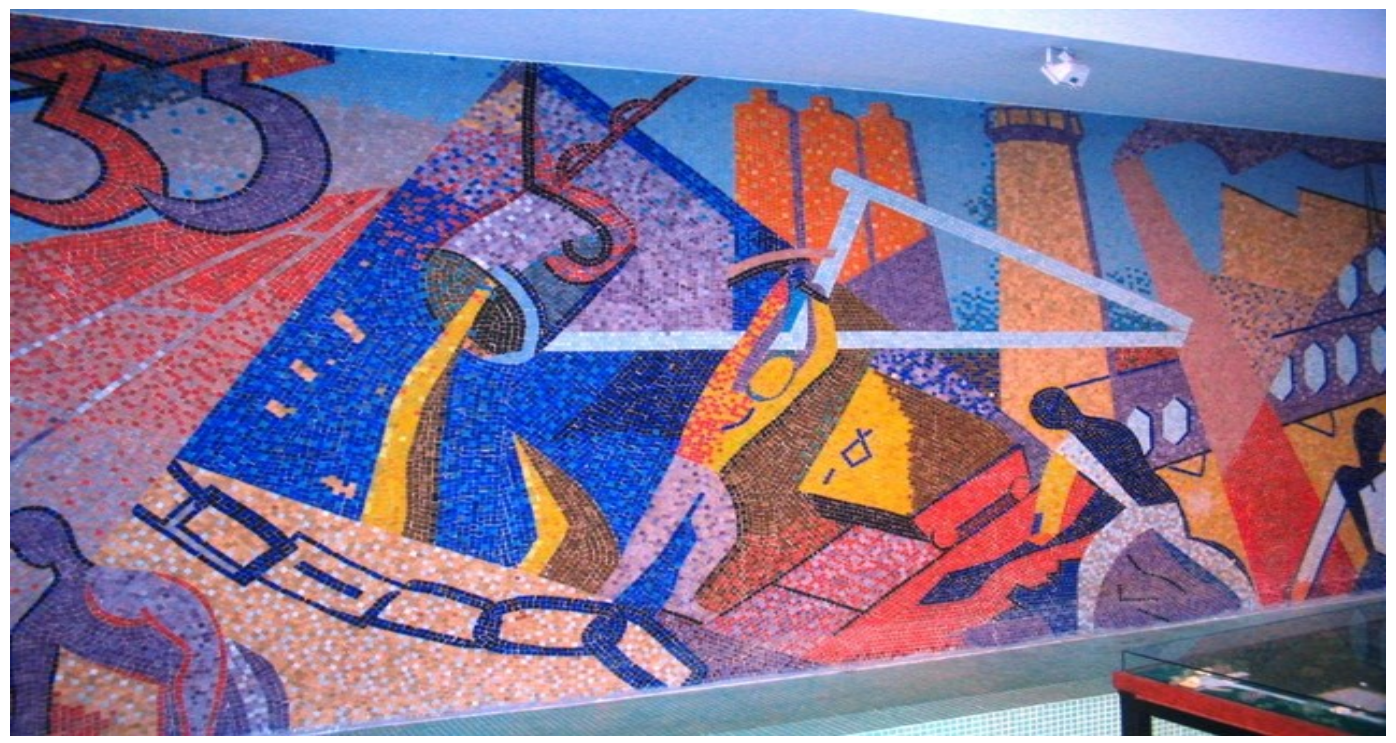

Fonte: Haro (1963).

Em concomitância com o movimento modernista vivenciado nacionalmente, Haro faz uso da arte mural como função social, exaltando a expressividade e grandiosidade da indústria catarinense, remetendo-nos com facilidade ao mural de Di Cavalcanti (Figura 6), o qual alude à dinâmica do trabalhador moderno. Inclusive as composições de cores em ambas as obras em muito assemelham-se.

\footnotetext{
${ }^{5}$ Declarado Patrimônio Cultural de Santa Catarina, pela Lei $n^{\circ}$ 14.128, de 05 de outubro de 2007.
} 
O mosaico, como um dos integrantes da arte mural, apresenta composição de elementos pequenos de cores diversificadas geralmente brilhantes, podendo ser constituído por pedras, cerâmica, vidro, pastilhas, entre outros materiais. Técnica muito antiga, descrita em relatos na Mesopotâmia em 3.500 a.C.

Figura 6 - Sem Título. Mosaico de pastilhas vítricas sobre parede.

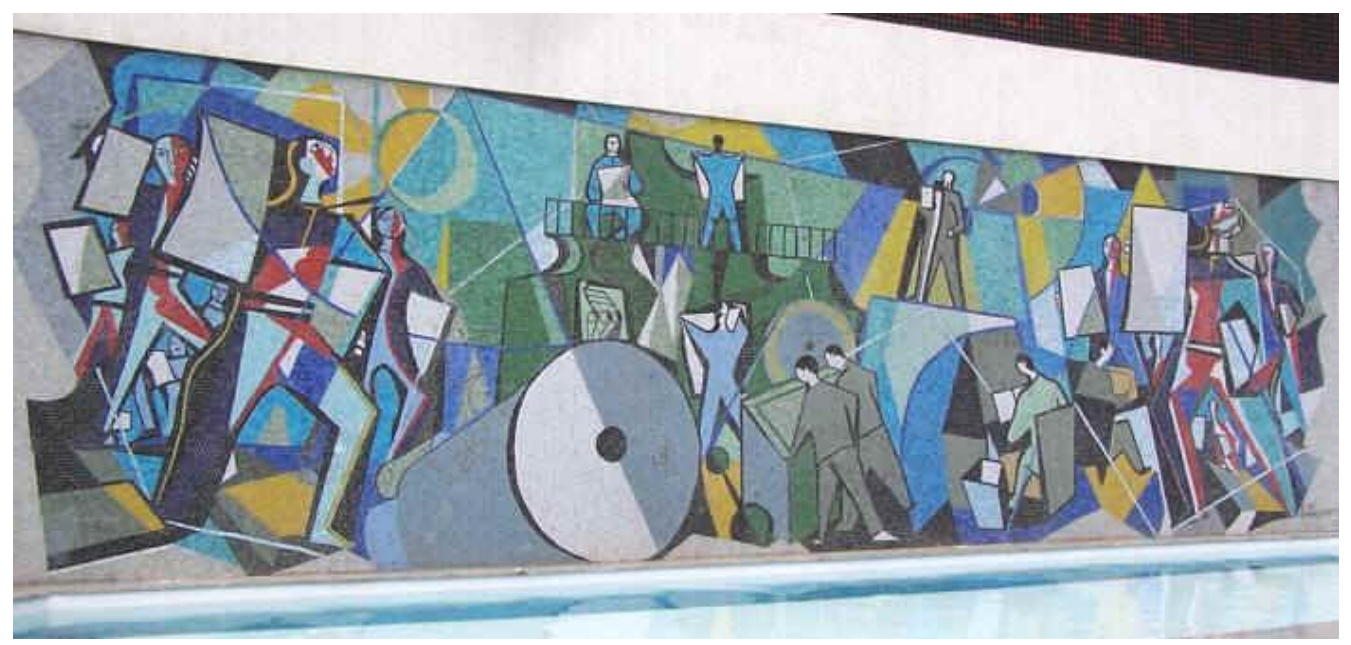

Fonte: Di Cavalcante (1952).

Na contemporaneidade, influenciados pelas ideias de Le Corbusier pelo texto $A$ Arquitetura e as Belas Artes (1984), somos direcionados ao olhar da arquitetura como forma de conjunção harmoniosa entre sua funcionalidade e a beleza e sensibilidade da arte simultaneamente, por meio da colaboração magnífica com as artes maiores: pintura e escultura. Parcerias são construídas entre arquitetos e artistas, permitindo que dentro da produção arquitetônica, a arte contribua para enaltecer as paredes, emergindo-as diante do olhar dos observadores. Enquanto no Rio de Janeiro surgia a parceria entre o arquiteto Oscar Niemeyer com Cândido Portinari, em São Paulo a parceria acontecia entre o arquiteto Rino Levi e Emiliano Di Cavalcanti.

Como exemplificação consistente dos princípios corbusianos, podemos mencionar o grande valor arquitetônico e artístico do Aeroporto de Congonhas, situado na região sul da cidade de São Paulo e construído em 1955, projetado pelo arquiteto Hernani do Val Penteado que, harmoniosamente, mesclou a art dèco com o modernismo efervescente, construindo, além de sua valoração funcional, uma verdadeira galeria de artes nas suas dependências. Ao todo, são 16 obras 
distribuídas por todo o terminal de passageiros entre pinturas, painéis, mosaicos e esculturas com assinaturas de renomados artistas, como Di Cavalcanti, Clóvis Graciano, Hernani Val Penteado, Raymond A. Jehlen, Jean Tranchant, Jacques Monet, Victor Brecheret, entre outros.

Para salvaguardar esse patrimônio histórico, o Conselho Municipal de Preservação do Patrimônio Histórico, Cultural e Ambiental da Cidade de São Paulo (CONPRESP) tombou, no ano de 2012, áreas do Aeroporto, considerando seu valor urbanístico, arquitetônico e afetivo, contemplando o Pavilhão das Autoridades, a Estação de Passageiros e uma estrutura de madeira em arco triarticulado dos hangares.

Destacamos a obra Os Trabalhadores, de Di Cavalcanti e Clovis Graciano (Figura 7), realizada em 1954 nas dependências do Pavilhão das Autoridades, situado no interior do Aeroporto de Congonhas/SP, como arte mural que dialoga com Martinho de Haro (Figura 5), tanto no ideário como na expressividade e enaltecimento nacionalista do trabalhador, gerador de riqueza e progresso.

Figura 7 - Os Trabalhadores.

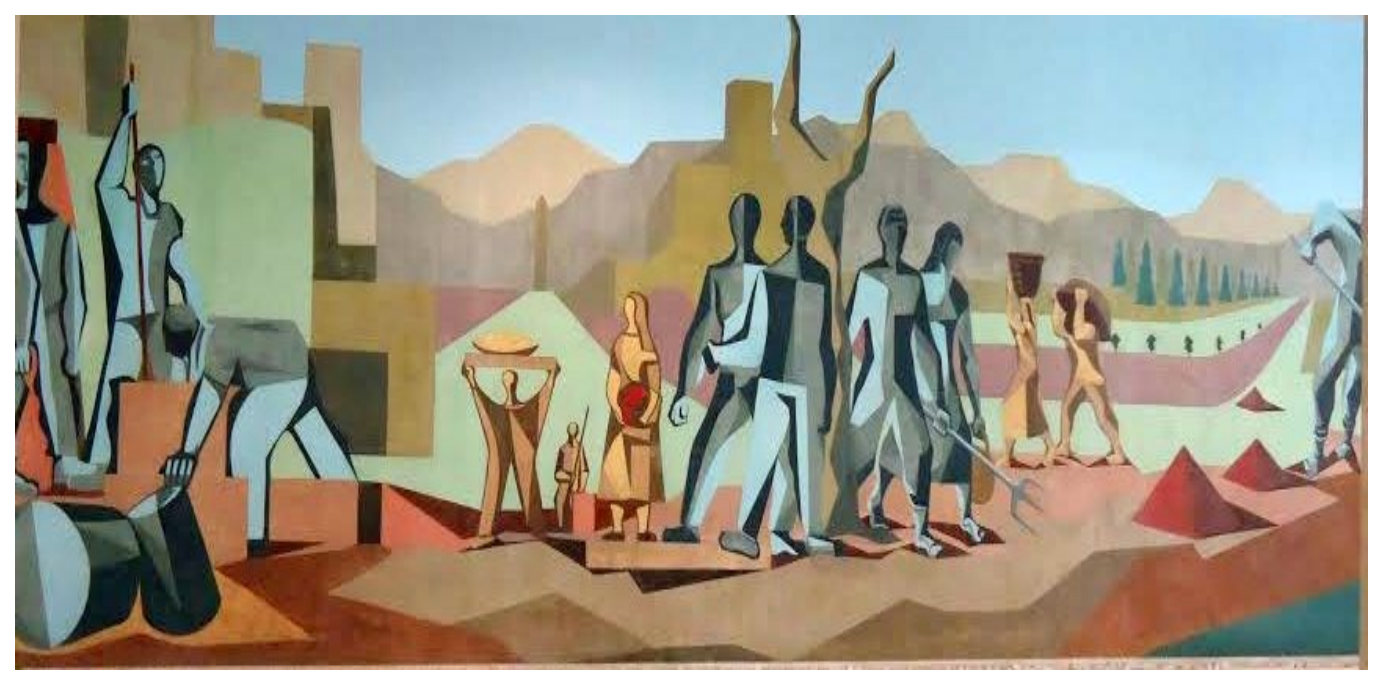

Fonte: Di Cavalcante e Graciano (1954).

Em Florianópolis, a construção modernista inicia em concomitância com o ciclo desenvolvimentista e progressista crescente nos anos 1950 no país. Da mesma forma que Portinari a convite do Governo Federal, realiza a construção pictórica mural que viria a torná-lo reconhecido mundialmente pela obra Guerra e Paz, Martinho de Haro recebe a incumbência, por meio do Governo Estadual de Celso Ramos, para a composição de uma obra mural no prédio da Federação 
das Indústrias de Santa Catarina (FIESC), inaugurado em 25 de novembro de 1963, na região central da cidade (Figura 5). Vale ressaltar que essa arte mural se realizou com plena concordância da linguagem funcionalista defendida por Le Corbusier, sendo estabelecida parceria entre os arquitetos da Moellmann \& Ráu com o artista referenciado.

Como um dos mais representativos exemplares da arquitetura modernista de influência corbusiana em São Paulo, o prédio sede do Jornal O Estado de São Paulo ${ }^{6}$, foi concebido por encomenda da Família Mesquita ao arquiteto Jacques Pilon em 1946. Porém, sofreu interferências na parte externa antes do começo de sua construção pelo arquiteto alemão Adolf Franz Heep em 1948, sendo a parceria com o artista Di Cavalcanti estabelecida em 1952, com a realização do mosaico no saguão aberto do térreo na inauguração da edificação (Figura 6).

De acordo com Zanini (1991), as obras de Clovis Graciano demonstram a influência que tiveram sobre ele as obras de Portinari. Vale rememorarmos que Portinari e Di Cavalcanti nutriam idolatria por Picasso e suas obras. Di Cavalcanti transparece intensamente em seus trabalhos sua forte admiração e influência também pelo movimento muralista mexicano de Diego Rivera, seja mediante seu engajamento da arte como função social, como por meio das formas arredondadas de suas figuras.

Salvo as localizações geográficas em que as obras foram constituídas, tanto Martinho de Haro (Figura 5), como Di Cavalcanti (Figura 6) e Clovis Graciano (Figura 7) representam com grandiosidade a arte mural e sua robusta função social a qual se destinaram em suas épocas, exaltando o nacionalismo que se inflamava no país diante do progresso industrial dos estados em plena pujança nacional.

Hassis, como carinhosamente ficou conhecido Hiedy, pode ser considerado como um dos mais atuantes artistas da região sul do país, dotado de extrema lucidez face aos problemas sociais de sua época. Apropria-se do muralismo como forma de expressão maior, fazendo de sua imponente obra mural Humanidade (Figura 8) um dos referenciais da sua produção artística. A obra localiza-se no interior da antiga Igreja da Paróquia da Santíssima Trindade, atualmente denominada como Igrejinha da UFSC por estar inserida no complexo do Campus Universitário da Trindade, pertencente à Universidade Federal de Santa Catarina (UFSC), situado na parede principal ao fundo do altar-mor. Sua composição constituída por $160 \mathrm{~m}^{2}$ representa sua maior obra em dimensões e

\footnotetext{
${ }^{6}$ Do térreo até o sétimo andar localiza-se o jornal e do oitavo ao $21^{\circ}$ andar, o Hotel Jaraguá.
} 
foi realizada entre 1978 e 1979. Hassis era artista plástico e funcionário público da UFSC, e colocouse à disposição do reitor para executar um mural, sem nada cobrar pela obra, ação esta aprovada rapidamente.

Figura 8 - Mural Humanidade.

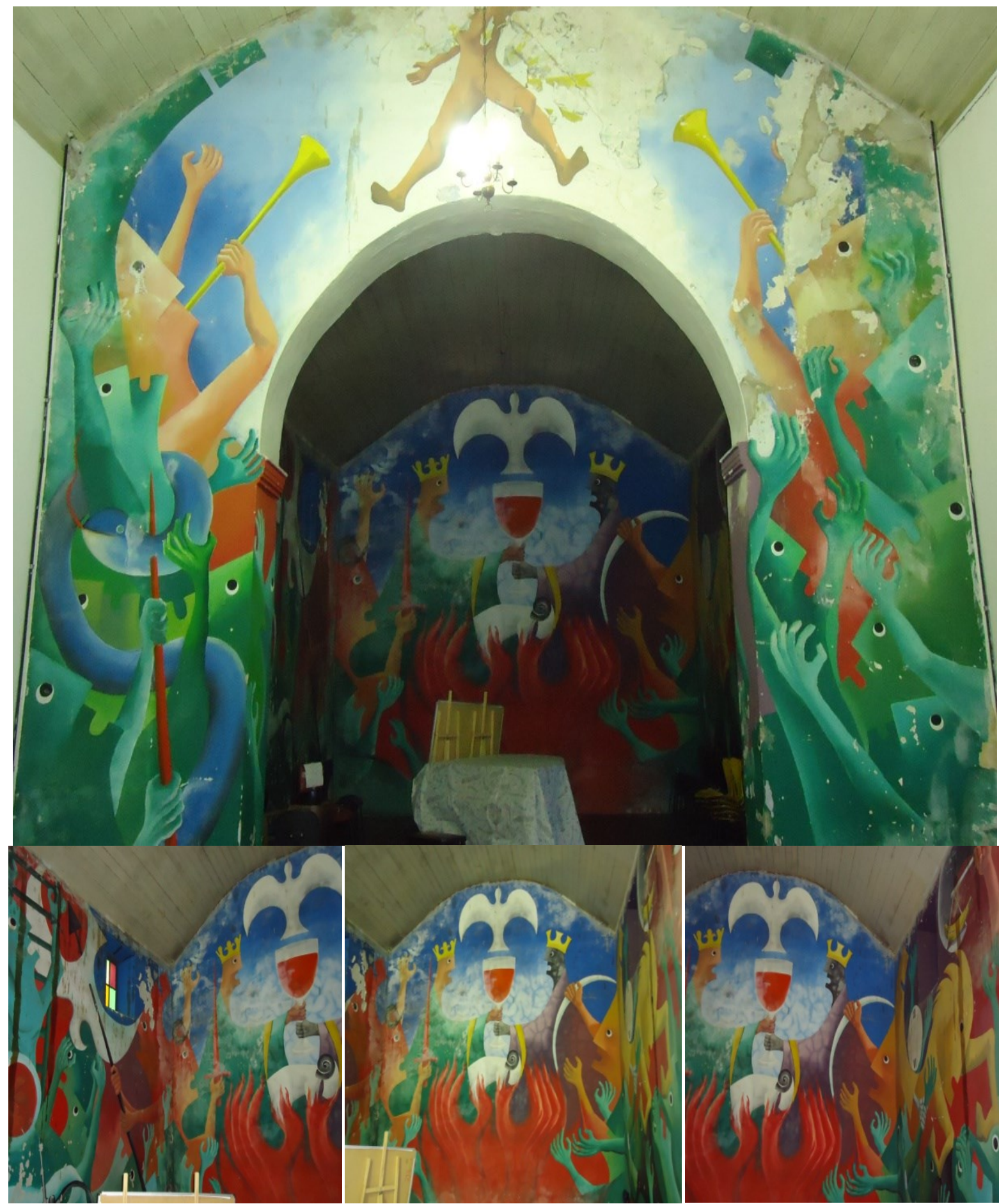

Fonte: Rubbi (2018). Acervo Pessoal. 
Perceptível sua similaridade de ideário com artistas de reconhecimento nacional (como Portinari e Di Cavalcanti) ao utilizar a arte muralista como função social, em combate explícito à violência e toda forma de opressão social de poder contra o povo. Talvez isso explique a defasagem entre sua imensa produção artística e o volume de comercialização de suas obras, porém isso nunca o desestimulou, pelo contrário, tornou-o mais criativo e fortaleceu seu espírito desafiador, buscando constantemente sua renovação artística.

De acordo com Werner (1993), do Departamento Artístico Cultural (DAC) da UFSC, sua criação originou-se de um período em que o reitor da Universidade na época, o professor Caspar Erich Stemmer, em reconhecimento do valor histórico da igrejinha, decide fazer uma restauração generalizada no local, com a finalidade de reutilização do espaço físico pelo departamento de atividades artísticas universitárias, servindo a apresentações de recitais de poesia, corais e orquestras de câmara sob supervisão geral do maestro Acásio Santana.

Sublinhamos que, em decorrência da construção da atual Igreja da Santíssima Trindade, sediada na Praça Santos Dumont, n. 94, quase ao lado da hoje conhecida Igrejinha da UFSC, construída em caráter de expansão da paróquia arquidiocesana católica, faz jus a reutilização do local realizada pelo reitor da época.

A obra apresenta movimento e forte dinamismo, com seres que gesticulam, quase em formato de alucinações. Mãos erguidas ao céu, como em súplica pela busca divina diante do apocalipse que se apresenta, o que facilmente remete-nos aos painéis Guerra e Paz, de Portinari, como também à Guernica, de Picasso, já referenciados neste trabalho. Ratificamos que esses pintores adentravam suas obras com o mesmo pensamento artístico, de forte cunho social, valendo-se do muralismo como forma de expressão mais abrangente e inclusiva da sociedade.

Ainda em Humanidade, no detalhe da lateral direita, observa-se um relógio sem ponteiros, no formato que muito lembra um sol, na tentativa de representar o tempo como esperança do despertar, no qual toda hora seria a oportunidade para um recomeço. Talvez não por coincidência esteja representado próximo à cor amarela, símbolo de calor e efervescência, em oposição às mãos erguidas e espalmadas na cor fria azul que envolve a figura do relógio, expressando clamor e dor. Do mesmo modo que no painel Guerra e Paz, as cores são utilizadas em forma de oposição de sentimentos. 
Percebemos também a chegada do cavaleiro negro do Apocalipse, que segura em suas mãos com punhos serrados, uma balança, em cujos pratos encontram-se, de um lado, uma banana e, do outro, uma barra de ouro, na alusão da opressão socioeconômica vivenciada pela sociedade da época. Talvez a banana expresse a ideia do pintor de fazer uso de produtos mais populares, acessíveis da população ou em representação da tropicália.

No alto dessa composição lateral, observa-se a sombra de um grande abutre, sugerindo a opressão e o orgulho desmedido por parte do governo. Um cavalo pintado na cor amarela, com duas patas em posição de galope, expressa o sentimento de resistência e esperança do povo, que, de boca entreaberta, grita em brados sons as injustiças sofridas.

Ao fundo, uma janela evidencia-nos a escuridão da noite que assola o presente, em profunda representação da chegada do Apocalipse. No painel, vemos a composição de cores quentes, como o amarelo e o vermelho, talvez na alusão do artista de mostrar a efervescência dos conflitos ardentes, que buscam a iluminação. Das cores frias da parte inferior do mural, emergem mãos aflitas, em cólera, mas dentre elas uma mão forte na cor branca agarra um braço em desespero, quiçá simbolizando que alguém os observa atento ao seu sofrimento e não hesitará em ajudar os suplicantes no momento certo.

Nas laterais do mural, figuras angelicais soam suas trombetas, anunciando a chegada do Salvador, que desce do céu, atendendo aos pedidos de súplicas. Entre corpos, uma serpente entrelaça-os na tentativa de aprisionar suas almas, espiralando-se com força em pleno domínio da obscuridade, que tenta impor-se diante da luz que vem do alto.

Da imagem central do cordeiro, Hassis introduz dois reis, o da direita na cor negra, e o da esquerda na cor branca, na alusão da perfeição divina e união étnica, em cujas mãos temos um cálice com sangue em demonstração da dor e do sofrimento que carregam da humanidade. $\mathrm{Na}$ lateral esquerda do mural, uma lança em diagonal apresenta-se, talvez na intenção de um remo de barco, remetendo-nos à trágica travessia para o inferno, descrita por Dante. Na parte inferior central do painel, mãos em chamas vindas do inferno, erguem-se como símbolo icônico da luta do bem e do mal, buscando pelo cálice sagrado, e sobre essas figuras dos reis observamos um pássaro branco, como símbolo do Espírito Santo, que busca incessantemente pela paz.

Podemos afirmar que o painel se baseia em um tripé icônico: anjos, demônios e serpentes, ávidos por possuírem as almas humanas. A composição de cores está constituída 
predominantemente pela pigmentação verde, azul, vermelha e branca, contribuindo fortemente para a dramaticidade do olhar apocalíptico do artista.

Figura 9 - O contestado: terra contestada.

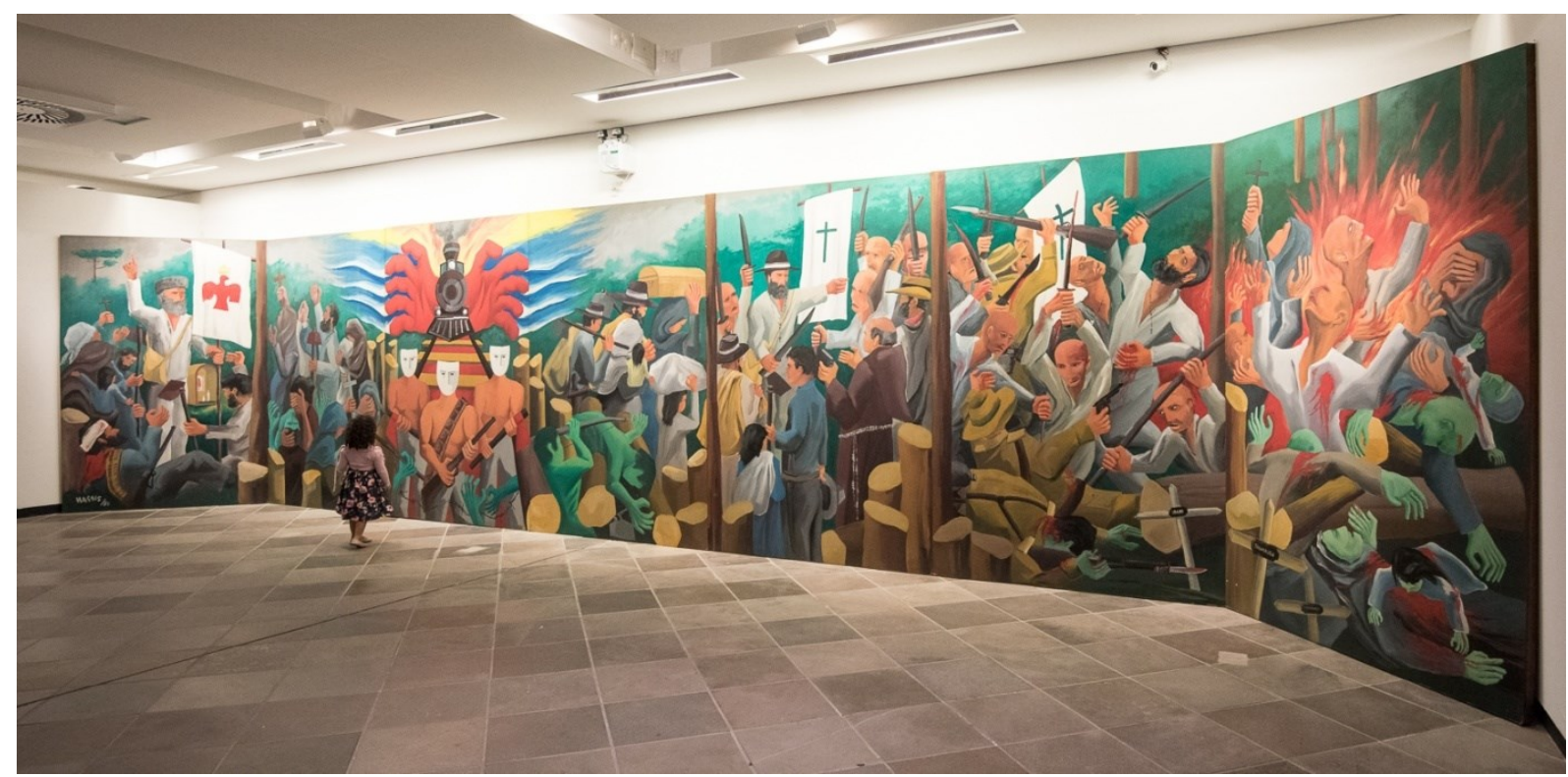

Fonte: Hassis (1985).

A arte mural de Hassis (Figura 9) e de Portinari (Figura 3) apresentam fortes similaridades nas expressões e funções sociais delatoras do ideário de ambos. A guerra e suas consequências civis expostas por figuras em cólera, dor e sofrimento, em que não raro a morte ronda. Braços estendidos em direção ao céu, com mãos espalmadas em formato de súplica, remetem-nos com facilidade aos braços pintados por Portinari, nos painéis referenciados. Em oposição, cores quentes como o vermelho e cores frias como o verde predominam na alusão da resistência que luta contra a opressão do poder que dilacera.

Tais dicotomias de cores também são observadas na obra de Portinari, salvo que este faz uso do calor do amarelo (obra Paz) e a frieza do azul (obra Guerra), mas ambos com a intencionalidade da dramaticidade aumentada. Em uma composição muralística com $36 \mathrm{~m}^{2}$, divididos em sete módulos de 2,75 m de altura por 1,80 m de largura cada um, essa obra, finalizada em 1985, contempla as fases históricas da Guerra do Contestado, com seus conflitos, sua religiosidade, o trem de ferro e seus personagens marcantes. É considerado o mais importante 
registro pictórico desse fato histórico que devastou o vale, matando cerca de 20 mil pessoas, representando um dos principais conflitos civis da região.

No painel da direita, observamos o fogo que inflama sobre figuras humanas, as quais erguem suas mãos na esperança da salvação vinda do céu, que tudo observa. Verossimilhante a Portinari, talvez a diferença seja encontrada na forte expressividade religiosa que Hassis descreve por meio de pinceladas, na qual a presença da figura de uma cruz aparece.

Enfatizamos que os artistas diferem sutilmente nos elementos de expressão. Portinari a nada se reporta que seja armamento bélico, enquanto Hassis evidencia tais equipamentos causadores dos mais nefastos sentimentos humanos, como o sofrimento e a morte.

De acordo com Boppré (2004), podemos citar que o acervo arquivístico de Hassis sobre a Guerra do Contestado continha fortes influências das memórias do seu avô paterno, Benedicto de Assis Corrêa, e de 15 livros bibliográficos, além de recortes de jornais e filmes, corroborando, de forma significativa, a construção desse grande painel, intitulado O Contestado - Terra Contestada (Figura 9), incentivado durante o governo do Estado de Esperidião Amim. No ano de 1984, portanto antes da obra referenciada, o artista produziu 78 desenhos em nanquim sobre papel, que serviram de estudos para a construção do painel de 12,60 m de largura por 2,75 m de altura, um ano após.

Como Portinari, Hassis mantinha grande admiração e idolatria por Picasso, inclusive com o hábito de citar as palavras do ídolo certa vez mencionadas: "Pinto o que sei, não o que vejo", reforçando as similaridades de pensamentos e metodologias artísticas aplicadas, valendo-se de toda potência imagética ao relatar a história. Toda composição artística de Hassis provém da sua memória e do diálogo nutrido com o presente. Dessa forma, eram constituídos suas temporalidades e seus espaços nas obras de arte. O artista utilizava o mural como suporte, pois acreditava na potencialidade que a liberdade do olhar proporcionava ao observador diante de dimensões maiores. Diversas vezes explorou o princípio do olho móvel como forma de poder visual artístico.

O mural encontra-se dividido, pelo próprio pintor, em quatro etapas: 1- chegada do monge João Maria e sua pregação; 2- vinda do trem, posse da terra, expulsão do caboclo, mercenários, morte e desmatamento; 3- chegada do novo messias, José Maria, para consolo dos caboclos e 12 pares da França, tendo como mediador o Frei Rogério; 4- Batalha de Irani, massacre de Taquaruçu, 
Caraguatá e outros lugares. São narrados quatro anos de história, representando uma verdadeira síntese espaço-temporal, perfazendo uma memorável narrativa histórico-iconográfica.

De certa maneira, somos remetidos também à famosa obra de Delacroix, A Liberdade Guiando o Povo, de 1830 (Figura 10), cujas similaridades impressionam nas figuras humanas que se erguem em brados fortes, entre mãos de punhos serrados, com espadas em punho, motivadas por fortes convicções sociais contrárias a toda forma de opressão da liberdade.

Figura 10 - A liberdade guiando o povo7.

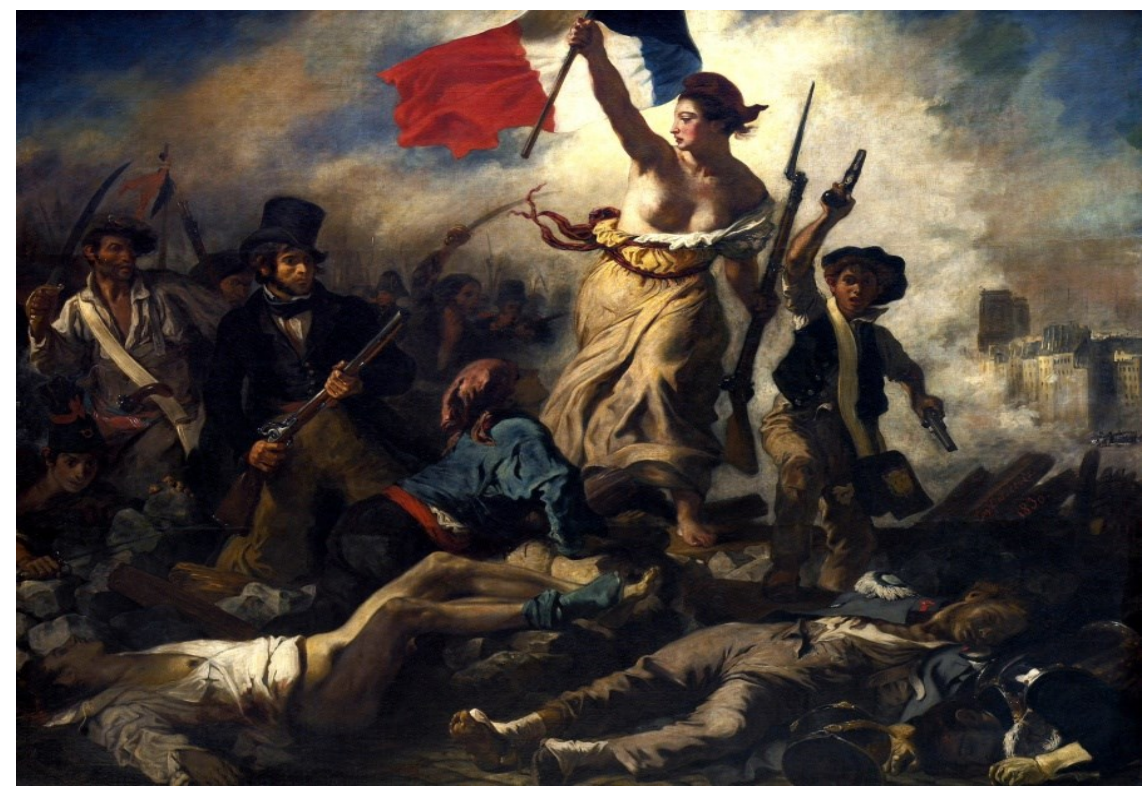

Fonte: Delacroix (1830).

A liberdade encontra-se vestida em ambas as obras, com figuras comuns do povo, que mancham suas próprias mãos e empunham espadas e armas modernas. Homens vivos e mortos são representados no sentido de unidade, como símbolo de um pertencimento de que todos fazem parte da luta, na qual o homem que morre pela bandeira, morre em forte união com a causa. Bandeiras, símbolo clássico de nacionalidade e convicções ideológicas, são empunhadas ressaltando a emoção do clamor popular na tentativa de reconquistar o seu orgulho e convicções perdidas, que, entre o predomínio das cores quentes como o vermelho diante da frieza do azul que insiste em rondar e do forte contraste de luz e sombra, fornecem de maneira contundente, maior

\footnotetext{
${ }^{7}$ Tradução de: La Liberté guidant le peuple.
} 
dramaticidade às obras, salvo as diferenças contextuais da temporalidade entre elas e do cunho histórico das lutas representadas nas telas, além da dimensão dos suportes.

\section{CONSIDERAÇÕES FINAIS}

A arte mural constitui-se por uma forte liberdade artística, que, livre da rigidez acadêmica, encontra sua potencialidade expressiva. Amparado pelas concepções do crítico Mario Pedrosa (1981) e da historiadora de arte Annateresa Fabris (1996), este trabalho consolida-se na tentativa de uma análise histórico-iconográfica que parte desde os primórdios da História da Arte para a contemporaneidade, enveredando pelos conceitos de Foucault, cujo tema da liberdade nunca esteve ausente, onde a abertura a experiências, num movimento contínuo, vislumbra um campo de possibilidades que transformam as relações que estabelecemos com o saber, conosco e com os outros, enaltecendo uma arte discursiva não homogênea e inexistente de neutralidade.

Neste trabalho, há a intencionalidade da exaltação e reconhecimento da potencialidade da arte mural, que não nasce na contemporaneidade, partindo da Antiguidade, sofrendo transformações temporais ao longo do caminho, perceptíveis na análise da iconologia e iconografia das obras as quais nos conduzem à seara histórica. Vale-se das imagens repletas de simbologias e signos que transbordam essências de conteúdos, cuja oralidade talvez não fosse capaz de contemplar com tamanha riqueza de detalhes a opulência e robustez contida nos estudos analíticos iconográficos.

Por meio do olhar sensível de Le Corbusier, vislumbramos a arquitetura moderna adentrando além dos aspectos do funcionalismo e racionalismo ortodoxo para a dimensão artística, a qual agrega valoração não apenas à obra, mas ao homem, conferindo poesia, tradição e emoção ao seu convívio. Essa confluência entre pintores, escultores e arquitetos corroborou, significativamente, a transformação do espaço urbano como arte ao coletivo, sem fruição limitada ou direcionada por circuitos.

Na cidade de Florianópolis, a Política de Arte Pública espelhou um amadurecimento conceitual que agregou valoração associativa entre a Arte Pública com a paisagem natural e cultural 
do Município, enaltecendo ainda mais o espaço público, especificamente em decorrência do incentivo previsto na Lei $\mathrm{n}^{\circ} 3.255$, de $1989^{8}$ (LUZ; PIRES, 2016).

Importante ressaltar que as imagens não são balizas fixas colocadas ao coletivo como completudes, mas sim como um sistema relacional mutável intrínseco de um processo que nunca se completa e que se ressignifica interminavelmente em cada novo olhar, desnudando a arte para o campo da dialética e das possibilidades infinitas.

A arte mural está inserida numa seara fascinante, repleta de ardências pessoais e coletivas que, de maneira democrática, exerce sua acessibilidade e ocupa seu espaço como função social de cunho imagético e contexto histórico da sociedade vigente.

\section{REFERÊNCIAS}

AMARAL, Aracy A. Arte para quê? A Preocupação Social da Arte Brasileira, 1930-1970: subsídios para uma história social da arte no Brasil. 3. ed. São Paulo: Nobel, 2003.

BONDONE, Giotto de. O Encontro de São Joaquim e Sant'Anna. 1304-06. Afresco 2,00 m x 1,85 m. Cappella Degli Scrovegni / Pádua - Itália.

BOPPRÉ, Fernando Chíquio. Hassis entre imagens ou A gaivota sempre está em movimento: do desenho ao Super 8 em Hassis. 2004. 150 f. Dissertação (Mestrado em História) - Universidade Federal de Santa Catarina, Florianópolis, 2004.

BROCOS, Modesto. A Retórica dos pintores. Rio de Janeiro: Typ. d’industria do Livro, 1933.

CLOTTES, Jean. Le grand panneau de la salle du fond. [20--?]. 1 fotografia. Disponível em: http://archeologie.culture.fr/chauvet/fr/mediatheque. Acesso em: 18 nov. 2019.

CORBUSIER, Le. A Arquitetura e as Belas Artes. Revista do Patrimônio Histórico e Artístico Nacional, Brasília, n. 19, p. 53, jan./jun. 1984. Disponível em: http://portal.iphan.gov.br/uploads/publicacao/RevPat19_m.pdf. Acesso em: 14 nov. 2019.

DELACROIX, Eugène. A liberdade guiando o povo. 1830. Óleo sobre tela (2,60 m x 3,25 m). Acervo Museu do Louvre/Paris.

\footnotetext{
${ }^{8}$ Lei $n^{\circ} 3.255 / 89$ tem por objetivo incentivar a inserção de obras de arte nas edificações acima de dois pavimentos, em suas fachadas e afastamentos frontais, com o intuito de incrementar a arquitetura e tornar mais belo e sensível o espaço urbano, mediante a concessão de benefício de acréscimo de $2 \%$ nos índices de construção, cujos princípios foram incorporados no Artigo 81 da Lei Complementar n001/97 (FLORIANÓPOLIS, 1989).
} 
DI CAVALCANTI, Emiliano. [Sem Título]. 1952. Mosaico de pastilhas vítricas sobre parede. Edifício Hotel Jaraguá.

DI CAVALCANTI, Emiliano; GRACIANO, Clóvis. Os trabalhadores. 1954. Mural de $56 \mathrm{~m}^{2}(16,00 \mathrm{~m} \mathrm{x}$ 3,50 m). Acervo do Aeroporto de Congonhas/SP - Pavilhão das Autoridades.

FABRIS, Annateresa. Cândido Portinari. São Paulo: Edusp, 1996.

FABRIS, Annateresa. Portinari, Pintor Social. São Paulo: Perspectiva, 1990. (Coleção estudos, v. 112).

FERRAZ, Ana Lucia Machado de Oliveira. Insigne presença: arte e arquitetura na integração dos painéis na obra de Rino Levi. 1998. 189 f. Dissertação (Mestrado em Arquitetura e Urbanismo) Escola de Engenharia de São Carlos, Universidade de São Paulo, São Paulo, 1998.

FOUCAULT, Michel. A Arqueologia do saber. Rio de Janeiro: Forense Universitária, 2009.

FLORIANÓPOLIS. Decreto-Lei Municipal n 3.255, de 03 de outubro de 1989. Autoriza execução de pinturas e/ou obras de arte nas edificações, cria incentivos e dá outras providências. Florianópolis: Câmara de Vereadores, 1989. Disponível em: https://leismunicipais.com.br/a/sc/f/florianopolis/leiordinaria/1989/325/3255/lei-ordinaria-n-3255-1989-autoriza-execucao-de-pinturas-e-ou-obras-dearte-nas-edificacoes-cria-incentivo-e-da-outras-providencias. Acesso em: 14 nov. 2019.

GOMES, Arthur. Considerações sobre a produção de pinturas murais no Rio de Janeiro das primeiras décadas do século XX. In: SIMPÓSIO CIENTÍFICO DO ICOMOS-BRASIL, 2., 2018, Belo Horizonte. Anais eletrônicos [...]. Belo Horizonte: ICOMOS, 2018. p. 4758-4777. Disponível em: https://www.academia.edu/37990158/2018__Considera\%C3\%A7\%C3\%B5es_sobre_a_produ\%C3\%A7\%C3\%A3o_de_pinturas_murais_no_Rio_de _Janeiro_das_primeiras_d\%C3\%A9cadas_do_s\%C3\%A9culo_XX. Acesso em: 14 nov. 2019.

HARO, Martinho de. [Sem Título]. 1963. Mural em pastilhas. Sede da FATMA.

HASSIS. Mural Humanidade. 1978-79. Pintura em Parede, $160 \mathrm{~m}^{2}$. Igrejinha da Universidade Federal de Santa Catarina.

HASSIS. O contestado: terra contestada. 1985. Pintura em acrílico sobre eucatex (1,26 m x 2,83 m). Acervo Museu do Contestado em Caçador/SC.

LEITE, José Roberto Teixeira. Dicionário crítico da pintura no Brasil. Rio de Janeiro: Artlivre, 1988.

LEONARDO Da Vinci. In: GUIA 101 gênios que mudaram a história da humanidade. Barueri: On Line Editora, 2016. 
LUZ, Tânia da; PIRES, Lú. Arte pública em Florianópolis: 1990-2015. Florianópolis: Letras Contemporâneas, 2016.

MARIANI, Ceci Maria Costa Baptista. Narrar artisticamente o Mistério Santo que habita entre nós: leitura místico-teológica da obra "Guerra e Paz" de Cândido Portinari. HORIZONTE: Revista de Estudos de Teologia e Ciências da Religião, v. 11, n. 31, p. 867-890, jul./set. 2013. Disponível em: http://periodicos.pucminas.br/index.php/horizonte/article/view/P.2175-5841.2013v11n31p867. Acesso em: 27 nov. 2019.

PANOFSKY, Erwin. O significado nas Artes Visuais. Rio de Janeiro: Editora Presença, 1989.

PEDROSA, Mário. Dos murais de Portinari aos espaços de Brasília. São Paulo: Perspectiva, 1981. (Coleção Debates, v. 170).

PICASSO, Pablo. Guernica. 1937. Óleo sobre tela (3,49 m x 7,77 m). Coleção Museu Nacional Centro de Arte Reina Sofía / Madri - Espanha.

PORTINARI, Cândido. Painéis Guerra e Paz. 1952-56. Óleo sobre madeira (14,00 m x 10,58 m). Sede da ONU / Nova York - EUA.

PORTINARI, João Cândido. Guerra e Paz: Portinari. Rio de Janeiro: Dom Quixote Editora, 2010.

PORTINARI, Cândido (1947: Buenos Aires, Argentina). In: Enciclopédia Itaú Cultural de Arte e Cultura Brasileira. São Paulo: Itaú Cultural, 2019. Disponível em:

http://enciclopedia.itaucultural.org.br/evento81203/portinari-1947-buenos-aires-argentina. Acesso em: 14 nov. 2019.

PRICE, Aimée Brown. L'esthetique decorative de Puvis de Chavannes. In: FOUCART, Jacques (org.). Paris: Editions Des Musees Nationaux, 1976.

ROSSETTO, Tania Regina; MORI, Nerli Nonato Ribeiro. Guernica: ancoragens e objetivações. Revista Teias, Rio de Janeiro, v. 17, n. 45, p. 203-217, abr./jun. 2016. Disponível em: https://www.epublicacoes.uerj.br/index.php/revistateias/article/view/24604. Acesso em: 14 nov. 2019.

RUBBI, Cristiane. Mural Humanidade, de Hassis (1978-79). 1 Composição iconográfica contendo 4 fotografias. Acervo Pessoal, álbum Hassis, de julho de 2018.

SANTA CATARINA. Decreto-Lei Estadual n 14.128, de 05 de outubro de 2007. Declara como Patrimônio Cultural de Santa Catarina os murais artísticos de Martinho de Haro. Florianópolis: Assembleia Legislativa do Estado de Santa Catarina, 2007. Disponível em: http://www.leisestaduais.com.br/sc/lei-ordinaria-n-14128-2007-santa-catarina-declara-patrimoniocultural-do-estado-de-santa-catarina-os-murais-artisticos-de-autoria-de-martinho-de-harolocalizados-no-colegio-industrial-do-municipio-de-lages-e-no-antigo-palacio-das-industrias-nomunicipio-de-florianopolis. Acesso em: 14 nov. 2019. 
SOUZA, Adelson Matias. O Muralismo de Rivera e Portinari: a arte como possibilidade de reflexão crítica e mediação com a realidade social. 2012. 60 f. Trabalho de conclusão de curso (licenciatura em Artes Visuais) do Instituto de Artes da Universidade de Brasília, 2012. Disponível em: http://bdm.unb.br/bitstream/10483/5650/1/2012_AdelsonMatiasSouza.pdf. Acesso em: 14 nov. 2019.

VALLE, Arthur. Prolegômenos ao estudo da pintura decorativa no Brasil das primeiras décadas do século 20. Arquitextos, São Paulo, 212.02, ano 18, jan. 2018. Disponível em: https://www.vitruvius.com.br/revistas/read/arquitextos/18.212/6863. Acesso em: 27 nov. 2019.

WERNER, Clóvis. Memória e patrimônio cultural: lembranças de um artista. Um exercício de justificativa para a preservação da antiga Igrejinha da Trindade. 1993. 125 f. Dissertação (Mestrado em História) - Universidade Federal de Santa Catarina, Florianópolis, 1993.

WILHELM, Vera Regina B. A arte mural do Grupo Santa Helena, um estudo para preservação. 2006. 150 f. Dissertação (Mestrado em Arquitetura e Urbanismo) - Faculdade de Arquitetura e Urbanismo, Universidade de São Paulo, São Paulo, 2006.

ZANINI, Walter. A Arte no Brasil nas décadas de 1930-40: o Grupo Santa Helena. São Paulo: Nobel, EDUSP, 1991. 